\title{
A Cytological Study of Triploidy in Pearl Millet
}

\author{
Panuganti N. Rao, A. Nirmala and P. Ranganadham \\ Department of Botany, Andhra University, Waltair 530 003, India
}

Accepted June 18, 1987

In pearl millet (Pennisetum americanum (L.) Leeke), triploids $(3 \mathrm{n}=21)$ arising spontaneously in diploid lines (Krishnaswamy and Ayyangar 1941, Pantulu and Rao 1977, Koduru and Rao 1978), in twins and triplets (Powell and Burton 1968), in the progenies of tetraploids (Burton and Powell 1968, Jauhar 1970, Gill et al. 1970) and through treatments with physical and chemical mutagens (Pantulu 1968, Manga 1972, Mani 1973, Singh et al. 1977) were reported. Isolated cases of hypertriploidy $(3 n=32)$ and hypotriploidy $(3 n=20$ and 19) also were on record (Jauhar 1981, Kumar et al. 1984). In the present study four spontaneous triploids, one hypertriploid and two hypotriploids were cytologically studied and the results are reported here.

\section{Materials and methods}

The triploids 33-20 and 17-7 were found in the first and second selfed generations of an open pollinated population of L.S. 356 obtained from Millet Research Station, Lam Farm, Guntur and two others 3-3 and 9-6 were located in the first selfed generation of an open pollinated Libyan population. In the open pollinated progeny of the triploid 33-20 a hypertriploid (33-20-7) and in those of 17-7 and 3-3 two hypotriploids (17-7-4 and 3-3-9) were found. Cytological studies were made during meiosis in PMCs using acetocarmine squash technique. Trivalent and quadrivalent type numbers were given after Darlington (1937).

\section{Observations and discussion}

\section{Morphology}

The triploids as well as hyper-and hypotriploids were more or less like their diploid sibs with two to three tillers. Pollen stainability ranged between 23 and $58 \%$. Seed set was nil on selfing but on open pollination or on crossing with diploid 6 to 15 seeds were obtained in the triploids and none from the hyper and hypotriploids.

Cytology of triploids $(3 \mathrm{n}=21)$

The triploids might have originated through mating of unreduced female gametes in a diploid $(2 n=14)$ with haploid male gametes $(n=7)$. Frequent trivalent formation (Table 1) confirmed their autotriploid nature (Figs. 1-3). Among the trivalents, all the four types, 7 (---), $\left.8(=-), 9()^{-}\right)$and $10(\bigodot)$ were found, though their relative frequencies varied in the different triploids (Table 2). The average frequencies of different chromosome associations and chiasmata per cell are presented in Table 3.

At anaphase I, a study of 180 to 200 cells in the four triploids revealed that $11: 10$ distribution was more common. Other distributions like 12:9, 13:8, 14:7 and 15:6 also occurred though to a lesser extent. One to three laggards were met with in a low percentage of cells. Tetrad formation was mostly normal, 4 to $13 \%$ of the tetrads showed one to three micronuclei. 
Earlier cytological studies in pearl millet triploids were few (Krishnaswamy and Ayyangar 1941, Pantulu 1968, Jauhar 1970, Gill et al. 1970, Manga 1972, Mani 1973, Singh et al. 1977, Koduru and Rao 1978). Among the spontaneous triploids, trivalent frequency per cell varied from 4.00 to 4.99 and chiasma frequency from 13.7 to 15.9 (Krishnaswamy and Ayyangar 1941, Koduru and Rao 1978, Present study). Of these, one was a translocation heterozygote

Table 1. Chromosome associations at diakinesis in four triploids of pearl millet

\begin{tabular}{|c|c|c|c|c|c|c|}
\hline \multicolumn{3}{|c|}{ Chromosome associations } & \multicolumn{4}{|c|}{ Number of cells in } \\
\hline III & II & I & $33-20$ & $17-7$ & $3-3$ & $9-6$ \\
\hline 7 & - & - & 5 & 8 & 21 & 12 \\
\hline 6 & 1 & 1 & 23 & 32 & 21 & 14 \\
\hline 6 & - & 3 & 1 & - & - & 1 \\
\hline 5 & 2 & 2 & 38 & 70 & 24 & 39 \\
\hline 5 & 1 & 4 & 1 & 1 & - & 2 \\
\hline 4 & 3 & 3 & 36 & 52 & 36 & 21 \\
\hline 4 & 2 & 5 & 7 & - & - & 4 \\
\hline 3 & 4 & 4 & 42 & 29 & 11 & 10 \\
\hline 3 & 3 & 6 & 2 & 1 & - & 2 \\
\hline 2 & 5 & 5 & 15 & 14 & 2 & 5 \\
\hline 2 & 4 & 7 & - & - & - & 1 \\
\hline \multirow[t]{2}{*}{1} & 6 & 6 & 5 & - & 1 & 1 \\
\hline & Tot & & 175 & 207 & 116 & 112 \\
\hline
\end{tabular}

Table 2. Percentage of types of trivalents and bivalents in four triploids of pearl millet

\begin{tabular}{|c|c|c|c|c|c|c|}
\hline \multirow{2}{*}{ Plant no. } & \multicolumn{4}{|c|}{ Trivalent type } & \multicolumn{2}{|c|}{ Bivalent type } \\
\hline & No. 7 & $\begin{array}{c}\text { No. } 8 \\
\text { No. }\end{array}$ & సั- & No. $\overbrace{10}$ & I & -- \\
\hline $33-20$ & 35.58 & 17.72 & 41.63 & 5.06 & 48.02 & 51.18 \\
\hline 17.7 & 38.97 & 14.42 & 44.02 & 2.26 & 59.26 & 40.73 \\
\hline $3-3$ & 50.00 & 0.35 & 49.48 & 0.17 & 66.96 & 33.04 \\
\hline $9-6$ & 53.21 & 3.02 & 43.21 & 0.56 & 68.72 & 31.27 \\
\hline
\end{tabular}

Table 3. Average frequency of chromosome associations and chiasmata per cell in four triploids of pearl millet

\begin{tabular}{ccccc}
\hline Plant no. & III & II & I & Chiasmata \\
\hline $33-20$ & 4.07 & 2.73 & 2.81 & 14.44 \\
$17-7$ & 4.49 & 2.50 & 2.49 & 15.22 \\
$3-3$ & 4.99 & 2.01 & 2.01 & 15.90 \\
$9-6$ & 4.71 & 2.19 & 2.46 & 15.19 \\
\hline
\end{tabular}

(Krishnaswamy and Ayyangar 1941). Compared to these, in the triploids obtained through treatments with mutagenic agents trivalent frequency was much variable and ranged from 3.57 to 6.35 and chiasma frequency from 15.7 to 19.4 (Pantulu 1968, Manga 1972, Mani 1973, Singh et al. 1977) and in those originating from crosses of tetraploid and diploid lines, the trivalent frequency was both low and narrow in range, 2.62 to 2.76 (Gill et al. 1970, Jauhar 1970). The significance of this association between the mode of origin of triploids and the trivalent 
frequency is not clear. Jauhar (1981) pointed out that variation in trivalent frequency in synthetic triploids is not unexpected because of the differences in the genetic background of the parental strains used. Despite the fact that the two source materials (L.S. 356 and Libyan population) in which the triploids were located in the present study were totally unrelated and genetically divergent, the variation in trivalent frequency among the four triploids is not wide. It is, therefore, believed that, besides genetic distinction, other factors that control the frequency and distribution of chiasmata and/or partner exchanges were involved in causing the recorded differences in trivalent ferquency in triploids of diverse origin.

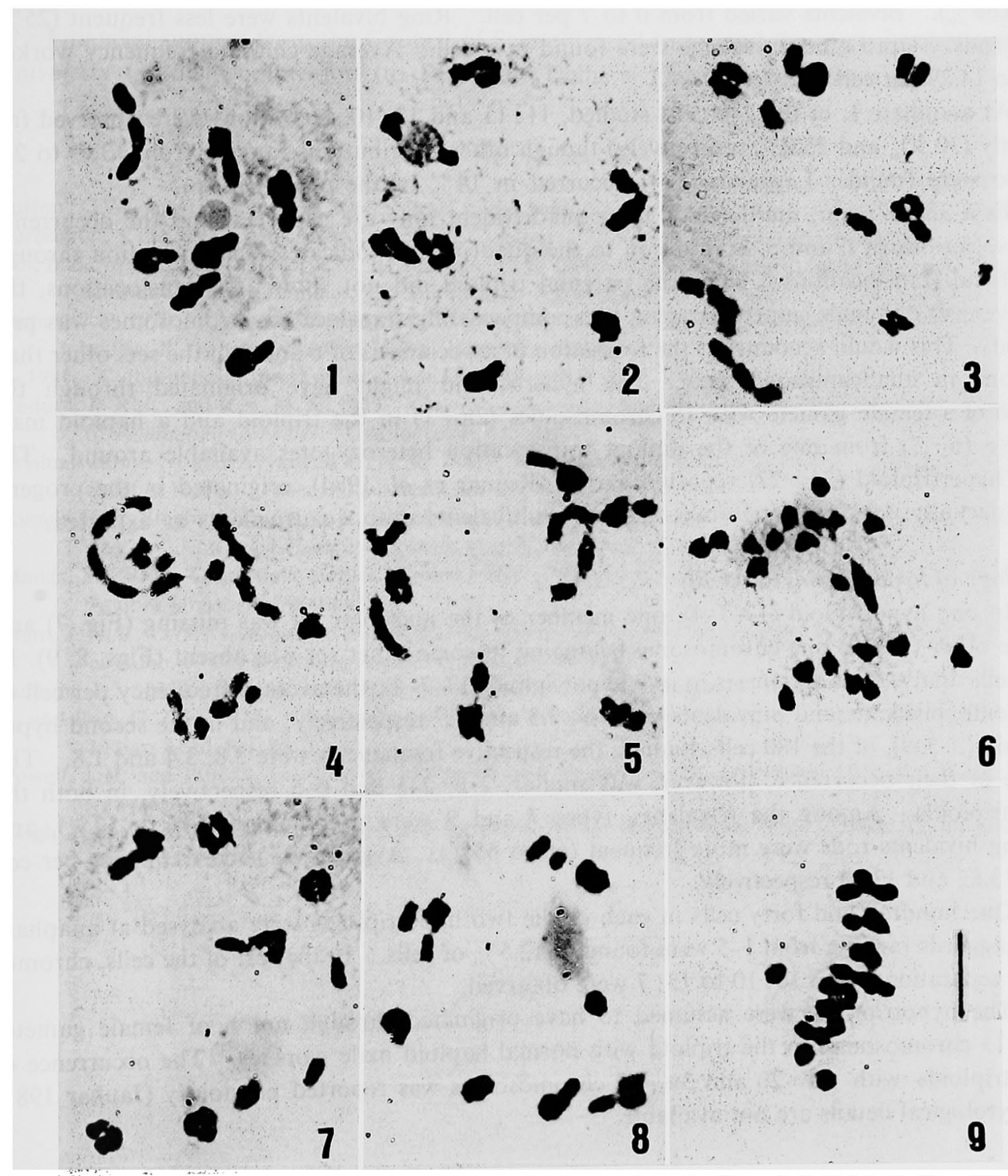

Figs. 1-9. Meiosis in triploids, hyper- and hypotriploids of pearl millet. 1-3: Triploids $(3 n=21)$. 1, diakinesis $7 \mathrm{III}$. 2, diakinesis $6 \mathrm{III}+1 \mathrm{II}+1 \mathrm{I}$. 3, diakinesis $5 \mathrm{III}+2 \mathrm{II}+2 \mathrm{I}$. 4-6: Hypertriploid $(3 n=22) . \quad 4$, diakinesis $1 \mathrm{~V}+1 \mathrm{IV}+3 \mathrm{III}+1 \mathrm{II}+2 \mathrm{I} . \quad 5$, diakinesis $1 \mathrm{IV}+6 \mathrm{III} . \quad 6$, anaphase I $11: 8$ with a bivalent and univalent as laggards. 7-9: Hypotriploids $(3 n=20)$. 7, diakinesis $4 \mathrm{III}+3 \mathrm{II}+2 \mathrm{I}$. 8, diakinesis $3 \mathrm{III}+4 \mathrm{II}+3 \mathrm{I}$. 9, metaphase I $5 \mathrm{III}+1 \mathrm{II}+3 \mathrm{I}$. Magnification bar is ten microns. 


\section{Cytology of hypertriploid $(3 \mathrm{n}=22)$}

A total of 141 cells were analysed at diakinesis in the hypertriploid. Associations of six, five and four chromosomes were observed with a frequency of $0.04,0.16$ and 0.28 per cell respectively. The maximum higher associations found in a cell were an association of six and a quadrivalent. Types of higher associations were either a branched chain of 6 or a chain of 5 (Fig. 4); among the quadrivalents, rings (type 17) and chains (type 11) (Figs. 4, 5) were predominant though some other types also occurred in a few cases. The frequencies of trivalents, bivalents and univalents per cell were $3.28,3.31$ and 3.31 respectively. Trivalents ranged from 0 to 5 per cell, and types 7 and 9 were more frequent $(41.09$ and $40.22 \%$ ) than type $8(18.69 \%)$. Bivalents varied from 0 to 7 per cell. Ring bivalents were less frequent $(25 \%)$ than rods. Upto nine univalents were found in a cell. Average chiasma frequency worked out to 14.29 per cell.

At anaphase I, of the 240 cells studied, 11: 11 and 12: 10 separations were observed frequently (30.3\% and $25.0 \%$ respectively) though other distributions ranging from $13: 9$ to 22 : 0 also were found. Laggards (1-4) occurred in $14 \%$ of the cells (Fig. 6).

In a $3 n+1$ plant, multivalents upto quadrivalent only are expected, and the occurrence of associations of 6 and 5, in addition to the quadrivalent, indicates their formation through reciprocal translocations. Since the pacental triploid did not show any translocations, the involvement of a male gamete carrying two compensating translocated chromosomes was presumed. This would account for the formation of associations of 6 and 5 in the sets other than the one in quadruplicated state. The hypertriploid might have originated through the fusion of a female gamete with 15 chromosomes $(2 n+1)$ in the triploid and a haploid male gamete $(n=7)$ from one of the diploid translocation heterozygotes available around. The only hypertriploid $(3 n=22)$ reported earlier (Kumar et al. 1984), originated in the progeny of a partially desynaptic trisomic, showed multivalents upto quadrivalents as expected.

\section{Cytology of hypotriploids $(3 \mathrm{n}=20)$}

In one hypotriploid (17-7-4), one member of the nucleolar set was missing (Fig. 7) and in the other (3-3-9) one chromosome belonging to some other set was absent (Figs. 8, 9). In 150 cells analysed at diakinesis in one hypotriploid (17-7-4), the average frequency per cell of trivalents, bivalents and univalents was $3.9,3.3$ and 1.7 respectively; and in the second hypotriploid (3-3-9), of the 180 cells studied, the respective frequencies were $3.8,3.4$ and 1.8 . The range of their occurrence, however, was similar, 2-6, 2-5 and 0-6 respectively, in both the hypotriploids. Among the trivalents, types 7 and 9 were predominant (48 to $52 \%$ ), and among bivalents rods were more frequent (60 to $65 \%$ ). Average chiasma frequency per cell was 13.82 and 13.69 respectively.

One hundred and forty cells in each of the two hypotriploids were analysed at anaphase I. Laggards ranging from 1-5 were found in $12.5 \%$ of cells. In the rest of the cells, chromosome separations from 10:10 to $13: 7$ were observed.

The hypotriploids were assumed to have originated through union of female gametes with 13 chromosomes in the triploid with normal haploid male gametes. The occurrence of hypotriploids with $3 n=20$ and $3 n=19$ chromosomes was reported previously (Jauhar 1981) but cytological details are not available.

\section{Summary}

In two wholly unrelated populations of pearl millet (Pennisetum americanum (L.) Leeke), four spontaneous triploids $(3 n=21)$ and in the progenies of triploids, one hypertriploid $(3 n=$ $22)$ and two hypotriploids $(3 n=20)$ were found. Cytological studies were made at meiosis 
on PMCs. In all these, trivalents, bivalents and univalents were found in varying frequencies. In the hypertriploid, however, besides a quadrivalent expected, associations of 6 and 5 chromosomes were also found indicating the presence of a reciprocal transolcation between non-homologous chromosomes. In one hypotriploid, a chromosome of the nucleolar set and in the second some other chromosomes in the complement were missing. While the triploids produced a few seeds, on crossing with diploid or on open pollintation, no seed set was found in hyper-and hypotriploids.

\section{Acknowledgements}

Financial support from the Council of Scientific and Industrial Research (to AN) and the University Grants Commission (to PR) New Delhi is gratefully acknowledged.

\section{References}

Burton, G. W. and Powell, J. B. 1968. Pearl millet breeding and cytogenetics. Adv. Agr. 20: 49-89.

Darlington, C. D. 1937. Recent Advances in Cytology. J. \& A. Churchill Ltd., London.

Gill, B. S., Minocha, J. L., George M. K. and Brar, D. S. 1970. Cytological studies in diploid, autotriploid and autotetraploid pearl millet. J. Res. Punjab Agric. Univ. 7: 417-422.

Jauhar, P. P. 1970. Chromosome behaviour and fertility of the raw and evolved synthetic tetraploids of pearl millet, $P$. typhoides Stapf et Hubb. Genetica 41 : 407-424.

- 1981. Cytogenetics of pearl millet. Adv. Agr. 34: 408-473.

Koduru, P. R. K. and Rao, M. K. 1978. Chromosome pairing and desynapsis in spontaneous autoplolyploids of Pennisetum typhoides. Cytologia 43: 445-452.

Krishnaswamy, N. and Ayyangar, G. N. R. 1941. An autotriploid in the pearl millet (Pennisetum typhoides Stapf et Hubb.) Proc. Indian Acad. Sci. 13: 9-23.

Kumar, R. S., Singh, U. P., Singh, R. B. and Singh, R. M. 1984. Meiotic behaviour in a hypertriploid plant of pearl millet (Pennisetum americanum (L.) K. Schum.). Genetica Agraria 38: 139-147.

Manga, V. 1972. Cytogenetic studies of pearl millet (Pennisetum typhoides Stapf et Hubb.). Ph. D. Thesis, Andhra University, Waltair.

Mani, J. N. R. 1973. Cytogenetic studies in some induced mutants of pearl millet (Pennisetum typhoides Stapf et Hubb.). Ph. D. Thesis, Andhra University, Waltair.

Pantulu, J. V. 1968. Meiosis in an autotriploid pearl millet. Caryologia 21: 11-15.

- and Rao, G. J. N. 1977. Genetically controlled chromosome numerical mosaicism in pearl millet. Proc. Indian Acad. Sci. 86: 15-22.

Powell, J. B. and Burton, G. W. 1968. Polyembryony in pearl millet, Pennisetum typhoides. Crop Sci. 8: 771-773.

Singh, R. B., Singh, B. D., Singh, R, M. and Laxmi, V. 1977. Meiosis in radiation induced triploid and tetraploid pearl millet. Cytologia 42: 633-637. 